\title{
Foraging geese, vegetation loss and soil degradation in an Arctic salt marsh
}

\author{
Jefferies, Robert L. ${ }^{*}$ \& Rockwell, Robert F. ${ }^{2}$ \\ ${ }^{1}$ Department of Botany, University of Toronto, 25 Willcocks St.Toronto, Ontario M5S 3B2, Canada; \\ ${ }^{2}$ Department of Ornithology, American Museum of Natural History, Central Park West, New York, NY 10024 USA; \\ ${ }^{*}$ Corresponding author; Fax +14169785878; E-mail jefferie@botany.utoronto.ca
}

\begin{abstract}
The North American mid-continent population of Lesser snow geese (Chen caerulescens caerulescens L.) has increased by ca. $7 \%$ per year, largely as a result of geese feeding on agricultural crops in winter and on migration. We describe the long-term effects of increasing numbers of geese at an arctic breeding ground (La Pérouse Bay, Manitoba) on intertidal salt-marsh vegetation. Between 1985 and 1999 goose grubbing caused considerable loss of graminoid vegetation along transects in intertidal marshes. Loss of vegetation led to bare sediment with a plant cover of less than $2 \%$. Changes in vegetation could not be described by simple linear, geometric or exponential functions; most losses occurred between 1988 and 1990 and losses were staggered in time between individual transects, some of which had all vegetation removed.

Between 1979 and 1999 the standing crop in July in remaining intact heavily-grazed swards of Puccinellia phryganodes and Carex subspathacea fell from 40-60 $\mathrm{g} \mathrm{m}^{-2}$ to 20-30 $\mathrm{g} \mathrm{m}^{-2}$. Intense grazing on remaining patches of sward has restricted growth of these clonal forage plants and hypersalinity of bare sediments has precluded re-establishment of vegetation. Between 1989 and 1993 numbers of faecal droppings in grazed plots reached maximum values of 15-22 droppings $\mathrm{m}^{-2} \mathrm{wk}^{-1}$. Since then peak values have remained at less than 13 droppings $\mathrm{m}^{-2} \mathrm{wk}^{-1}$. The loss of vegetation and changes in soil conditions have resulted in the establishment of an alternative stable state (hypersaline bare sediment).
\end{abstract}

Keywords: Faecal density; Grazing, Grubbing; Lesser snow geese; Species assemblage; Standing crop.

Nomenclature: Porsild \& Cody (1980).

\section{Introduction}

Herbivores strongly influence plant community dynamics (Harper 1969; Crawley 1983; Huntly 1991; Sinclair 1995; Olff et al. 1999). Besides their effects on the abundance and standing crop of different species, herbivores can also influence the physical structure of the environment, particularly the soil-plant continuum (Graetz 1991; DeAngelis 1992; van de Koppel et al. 1997; Jefferies 1999). The effects of herbivores and changes in physical processes result in irreversible transitions in community assemblages leading to discontinuous multiple stable states (Holling 1973; Noy-Meir 1975; May 1977; Westoby et al. 1989).

Abrupt and rapid changes between stable states are often caused by positive feedbacks (Maruyama 1963; DeAngelis et al. 1986; Oksanen 1990). For example, limited vegetation loss can be amplified into large-scale desertification by positive feedbacks between plant mortality, soil degradation processes and inability of plants to re-establish (Graetz 1991; Srivastava \& Jefferies 1996). The initial vegetation loss that triggers such changes of state is frequently linked to increasing herbivore populations.

Herbivore populations are often kept in check by negative feedbacks linked to food sources (resource limitation) or to predators (density-dependent predation). When predators are absent, herbivore populations can increase dramatically, resulting in a trophic cascade and a sustained reduction in the biomass of primary producers that lead to changes in plant and animal assemblages (Paine 1969; Lawton 1989; Power 1992; Strong 1992; Polis \& Strong 1996). The same effect also may occur if consumers increase in numbers as a result of an external food subsidy without, necessarily, a concomitant increase in predators (Polis 1999). In this paper we use the term 'apparent trophic cascade' to describe the cascading effects of a burgeoning population of snow geese on intertidal vegetation and soils that have led to ecosystem changes. In the absence of increased predation this 
herbivore has grown in numbers in response to a trophic subsidy.

The North American mid-continent population of the Lesser snow goose (Chen caerulescens caerulescens L.) has been increasing in recent decades at an annual rate of 5-7\% per year (Cooke et al. 1995; Abraham et al. 1996). The sustained increase in population size is thought to be the result of increased dependence of the birds on trophic subsidies, i.e. agricultural food sources and food provided in refugia on wintering grounds and along flyways (Hobaugh et al. 1989; Alisaukas \& Ankney 1992; Abraham et al. 1996; Jefferies et al. 2002). These additional food sources, coupled with only a limited increase in predation from the main predator (herring gulls), on the breeding grounds (R.F. Rockwell unpubl.) have removed the negative feedbacks that might have checked population growth. The breeding colony of lesser snow geese at La Pérouse Bay on the coast of Hudson Bay in northern Manitoba has increased in size from 1300 pairs in 1968 to an estimated 44500 pairs in 1997 (Cooke et al. 1995; Abraham et al. 1996 unpubl. aerial survey). Similar increases have occurred in other breeding populations of mid-continent snow geese (Abraham et al. 1996).

The increase in snow goose numbers has resulted in a widespread consumption of coastal vegetation at breeding colonies around the shores of Hudson Bay. High consumption rates have led to loss of vegetation cover, exposure of surface sediments and development of hypersaline soil (Bazely \& Jefferies 1997). Changes to the intertidal salt marshes are the outcome of an apparent terrestrial trophic cascade that results in an alternative stable state (Hik et al. 1992; Bazely \& Jefferies 1997). Loss of vegetation and development of hypersalinity are brought about by a positive feedback, a consequence of both the foraging activities of geese and abiotic changes in soil properties (Iacobelli \& Jefferies 1991; Srivastava \& Jefferies 1996). The vegetational changes in the coastal marshes over the past decades have been detected by multi-temporal analysis of LANDSAT data (Jano et al. 1998).

In this paper we report long-term changes in vegetation of the intertidal flats that have occurred since 1985 in response to the foraging activities of the geese, as well as changes in the use of the flats by geese. These data can be interpreted in relation to the above conceptual framework and provide support for the occurrence of multiphasic processes that result in an alternative stable state.

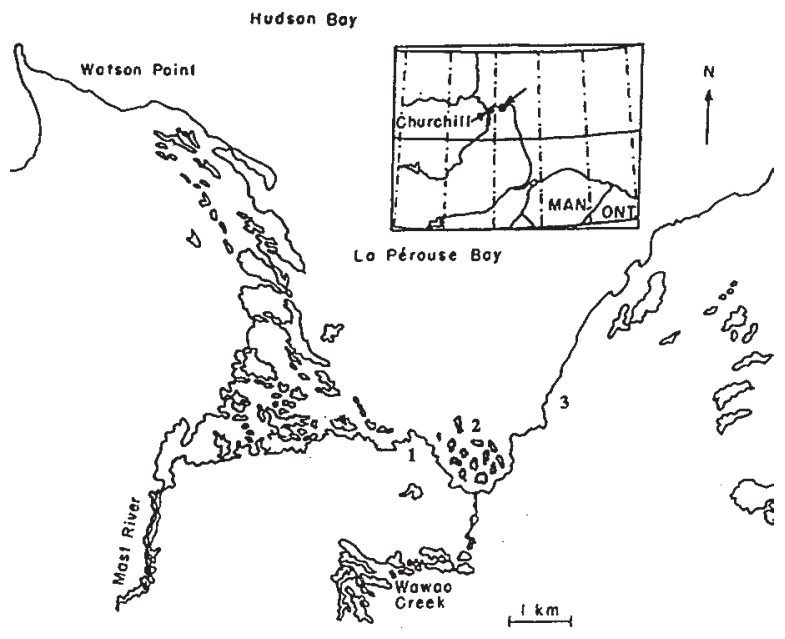

Fig. 1. Map of La Pérouse Bay. Its position on the Hudson Bay coast is indicated by an arrow on the inset map. Location of transects: 1. Western intertidal salt marsh (transects 1 -4); 2. Island salt marshes (transects 5-8); 3. Eastern intertidal salt marsh (transects 9 - 12).

\section{Site description}

Extensive intertidal flats occur at La Pérouse Bay, Wapusk National Park, Manitoba (58 $45^{\prime} \mathrm{N}, 93^{\circ} 30^{\prime} \mathrm{W}$ ) as a result of isostatic uplift which, in the Cape Churchill region, is ca. $0.8 \mathrm{~cm} \mathrm{yr}^{-1}$ (Hansell et al. 1983). The increase in elevation inland from the coast is ca. $1 \mathrm{~m}$ for every $3000 \mathrm{~m}$ of coastal marsh. At the confluence of the east and west sections of this V-shaped bay, shallow, braided streams of the Wawa Creek produce a highly dissected shoreline where there are a number of small islands interspersed between stream channels (Fig. 1). Shallow tributaries of the Mast River also flow into the bay across the western salt marsh, but the eastern salt marsh is largely devoid of freshwater drainage channels and the only sources of water are shallow ponds in the upper intertidal marsh that frequently dry out in latespring and summer. The flats away from drainage channels were formerly covered with a sward of Puccinellia phryganodes and Carex subspathacea in which Potentilla egedii, Plantago maritima and Stellaria humifusa were common. Much of this vegetation has been lost as a result of goose foraging. Close to freshwater or brackish streams Hippuris tetraphylla, C. subspathacea and Ranunculus cymbalaria are still abundant. In the extreme upper levels of the salt marshes Festuca rubra and Calamagrostis deschampsioides replace the dominant graminoids, Salix brachycarpa and S. myrtillifolia are present (Jefferies et al. 1979), although most grass swards have been destroyed. 


\section{Material and Methods}

\section{Long-term changes in vegetation along permanent transects}

In spring 1986 permanent transects were established in the Puccinellia-Carex zone of the intertidal salt marshes at La Pérouse Bay, 4 in each of the western (numbers 1-4), eastern (9-12) and island (5-8) marshes. Each transect consisted of 2 secondary transects set perpendicular to each other at their midpoints. Lengths of transects varied, depending on the terrain, but the total length of all transects was $803 \mathrm{~m}$. Transects were positioned at random in the mid and upper sections of each marsh, depending on the location of the graminoid assemblage, although some destruction of swards had already occurred prior to establishment of the transects. Each year (except 1983), in June or early July, the vegetation was recorded along a transect at $1 \mathrm{~cm}$ intervals (i.e. along the 2 secondary transects). The survey included bare exposed sediment where plant cover was absent or $<5 \%$ and a Puccinellia phryganodes-Carex subspathacea-moss-Cyanobacteria assemblage where the basal coverage of vascular plants was at least $5 \%$. At all sites grazing and/or grubbing had led to loss of some plant cover; intact swards were no longer present throughout the entire length of each transect when they were established.

As our objective was to determine the increase in bare sediment since 1986, we identified 2 states, bare sediment and plant cover exceeding $5 \%$. Hence, the data represent a very conservative measure of the vegetated state. Additionally, data of the 2 secondary transects at a site were combined. In summary, the total of the different frequencies for a transect is the total number of $\mathrm{cm}$ of the 2 states. We evaluated changes in the distribution of the 2 states over time using log-linear models of the cross-classified data, an approach sometimes referred to as multidimensional contingency analysis (Bishop et al. 1975). The distribution of states was a response variable while year, transect and position along the shore of the bay were considered to be classification variables. Since the objective was to determine changes in the relative proportions of the 2 states over time we only considered models that included the 2 nd order term involving state and year, and only values associated with this are given in the Results. This constraint is consistent with the fixed nature of each transect over time (cf. Fienberg 1980; Everitt 1992). The log-linear models used to determine dependency of state type on year for each transect and for each marsh in the bay were generated using the CATMOD procedure from $\mathrm{SAS}^{\mathrm{R}}$ 6.12. Effects were evaluated statistically using the Wald statistic with significance of 2nd, 3rd or higher-order terms con- firmed with the use of a log-ratio chi-square statistics of the less saturated model (Stokes et al. 2000). Since the nature of hierarchical model analysis requires repeated evaluation of subsets of the data, we have reduced inflation of our overall $\alpha$-error rate with a Bonferroni approach that requires $P<0.002$.

Log-linear models of cross-classified data evaluate whether the relative distribution of the 2 habitat types has changed over time and whether the change depends on specific marshes and transects within marshes. They provide no insight of the specific pattern of change. While it is possible to construct specific models that might mimic detected changes, it is more prudent to initially demonstrate whether the changes are consistent with patterns predicted from models of simple processes. Our general approach is therefore as follows: given the initial (1986) and final (1997) points for any given transect we asked whether the pattern displayed by the intervening samples is consistent with predictions from specific models. We used models corresponding to 3 simple and basic processes; linear, geometric and exponential change. As the distribution of habitat types is dichotomous, we can depict the patterns as the proportion of bare soil at time $t\left(\mathrm{~b}_{\mathrm{t}}\right)$. The single step and recursive equations for each are:

$\begin{array}{lll}\text { Process } & \text { Single-step } & \text { Recursive } \\ \text { Linear } & b_{t}=b_{t-1}+k & b_{t}=b_{0}+t k \\ \text { Geometric } & b_{t}=b_{t-1}+\lambda & b_{t}=b_{0} \times \lambda^{t} \\ \text { Exponential } & b_{t}=\left(b_{t-1}\right)^{\phi} & b_{t}=\left(b_{0}\right)^{\phi t}\end{array}$

Estimates for the constants associated with each process were obtained algebraically from the recursives by setting the estimate of the proportion of bare soil in 1997 to $b_{t}$, the comparable estimate in 1986 to $b_{0}$ and using $t=$ 11. Separate estimates were obtained for each transect.

For a given transect, the proportion of bare soil in the intervening years (1987 to 1996) was projected for each process using the single-step equations. These proportions were then multiplied by the total length examined in a given year to give the expectations for the bare soil category, and ( 1 - the proportion) was used to generate the expectations for the vegetated category. The fit of the expected values from 1987 to 1996 to the observed values was evaluated with the Log ratio chi-square. In those cases where proportions were equal to 1 or 0 , a small adjustment equal the reciprocal of the sample size of the year for a given transect was subtracted or added, respectively, to allow evaluation of natural logarithms. These small adjustments had no impact on the magnitude of the overall Log ratio chi-square values. The observations for 1986 and 1997 were excluded in calculating the log ratio chi-square as they were used in estimating the constants and their 'fit' would be perfect. The data for each of the 12 transects were analysed in 
relation to the 3 different projections. To guard against inflation of the overall $\alpha$-error rate, we applied a Bonferroni correction that required $P<0.05 / 36 \leq 0.001$ for significance of any log ratio chi-square value. The $\log$ ratio chi-square values were evaluated with $10 \mathrm{de}$ grees of freedom owing to the bivariate nature of samples within a year.

\section{Long-term changes in above-ground biomass of grazed intertidal swards}

Above-ground biomass $\left(\mathrm{g} \mathrm{m}^{-2}\right)$ of the western intertidal salt marsh was determined during the snow-free months in most years from 1979 to 1999 , based on the procedures of Cargill \& Jefferies (1984). In some years (e.g. 1982) few harvests were made. At the start of each season 6 permanent plots $(4 \mathrm{~m} \times 4 \mathrm{~m})$ were established at random in intact grazed swards of $P$. phryganodes and $C$. subspathacea. The plots were positioned at intervals along the length of the western marsh (parallel to the shore). A turf $(10 \mathrm{~cm} \times 10 \mathrm{~cm})$ was taken at random from each plot at each weekly sampling occasion and the above-ground plant biomass was cut, floated in trays of water and the live green biomass collected, dried and weighed. Amounts of necromass were negligible. In most years (except 1982) plots were sampled in July, at which time the standing crop of ungrazed salt-marsh vegetation reached a seasonal maximum (Cargill \& Jefferies 1984). Samples were also often taken in June and August. The biomass values provided an index of the intensity of grazing by the birds of their preferred forage species (Gadallah \& Jefferies 1995), particularly in July when demand by family groups for forage was highest.

\section{Measurement of faecal densities in grazed intertidal swards}

To obtain an index of the use of the western intertidal salt marsh by geese weekly faecal counts were made in most years between 1982 and 1999. Six additional permanent plots $(4 \mathrm{~m} \times 4 \mathrm{~m})$ were established in grazed swards across the marsh and the droppings were counted weekly, after which all droppings were removed. In late July and August in some years tides covered the marsh preventing measurement of rates of faecal deposition. No attempt was made to distinguish between droppings of goslings and adult geese.

\section{Results}

\section{Long-term changes in vegetation}

Changes in the proportion of bare soil compared to that of the vegetated state ( $>5 \%$ plant cover) along transects are shown in Fig. 2 and analyses of data based on changes within and between transects, years and states (bare sediment and the vegetated state) are given in Table 1. Since the data of transects are considered to be samples of each marsh rather than fixed factors there are 13824 different ways the data could be cross-classified. While estimates of source effects can differ among the various cross-classifications, results given in Table 1 are typical. In more than 100 cases examined all 4 sources involving state and year were significant at $P<$ 0.0001 and the approximate magnitude and rank order of the Wald statistics were the same across sources. The significance of the 4 th order term indicates that state changes depend on unique combinations of transect and marsh.

This requires a more detailed evaluation of the dependency of state in relation to year for transects and marshes (Table 2). For each marsh, the 3rd order model indicates that state changes over time depend on specific transects. Separate 2 nd order models were evaluated for each transect and are summarized below the 3rd order model in Table 2 for the 3 marshes. In each case the proportion of the 2 states varies significantly over time. While the precise pattern of change differs among transects within each marsh (consistent with their significant 3rd order terms), there are similarities in patterns both within and between marshes. In all cases, the proportion of bare soil increased significantly over time $(P<0.0001)$ (Table 2$)$ with much of the change occurring between 1988 and 1989 .

It is also evident that patterns of change among transects are different for the 3 marshes. In the western intertidal salt marsh the rate of removal of vegetation by geese after 1989 is more delayed along transect 4 than transects 1 and 3 , the pattern for transect 2 is intermediate between these data sets (Fig. 2a). In the braided estuary of Wawa creek a similar delay in removal of vegetation is seen along transect 8 (Fig. 2b). In contrast to the above results, patterns of vegetational change along transects in the eastern intertidal salt marsh are similar over time (Fig. 2c). These differences between marshes are the likely source of the significant 4 th order term in Table 1, and reflect differences in elevation that influence the extent of ice and melt water coverage of transects in spring. They are also reflected in the extent of disparity among the Wald statistics for transects between marshes. For example, Wald statistics range from 4966 to 33464 for the western intertidal salt marsh, 
but only 1245 to 17823 for the eastern intertidal salt marsh.

The vegetated state was absent from some transects in later years as a result of goose grubbing. These represented ' $0 \mathrm{~s}$ ' in the cross-classification of the data and this can lead to difficulties when evaluating data using log-linear models (Fienberg 1980; Everitt 1992). As indicated in Tables 1 and 2, the degrees of freedom of some higher order terms are below expectation. This reduces the power of the Wald statistic and the log-ratio chi-square values of reduced models to detect significant dependency of response variables on classification variables. Since all those tests are significant, the power problem does not affect our general conclusions. However, since the ' 0 ' cells were excluded from the analysis we further examined the dependency of state on year by setting the 0 cells to 1 (Stokes et al. 2000) and rerunning the analyses. Although this increased the magnitude of the test statistic (which is dependent on the total number of samples), our increase in sample size was so small (from $0.001 \%$ to $0.02 \%$ depending on the
Table 1. Log-linear model of the data set of loss of the vegetated state and the change to bare sediment based on transect and year on intertidal marshes at La Pérouse Bay, Manitoba between 1986 and 1997. $P<0.0001$ for all cases.

\begin{tabular}{llc} 
Source & df & Wald statistic $^{\text {b }}$ \\
\hline State*year & 11 & 61990.07 \\
State*year*transect & 33 & 4416.43 \\
State*year*marsh & 22 & 2868.62 \\
State*year*transect*marsh & $47^{\mathrm{a}}$ & 12779.97
\end{tabular}

aDegrees of freedom depart from expectation owing to cells containing

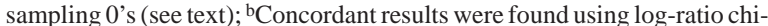
square values of reduced order models (Stokes et al. 2000).

analysis) that the increase in sample size was of little consequence. The results did not lead to conclusions that differed from those based on analyses summarized in Tables 1 and 2 .

Our log-linear model analyses demonstrated that the relative distribution of the 2 habitat types changed significantly over the 11 years and the precise nature of the change differed among the transects even though there
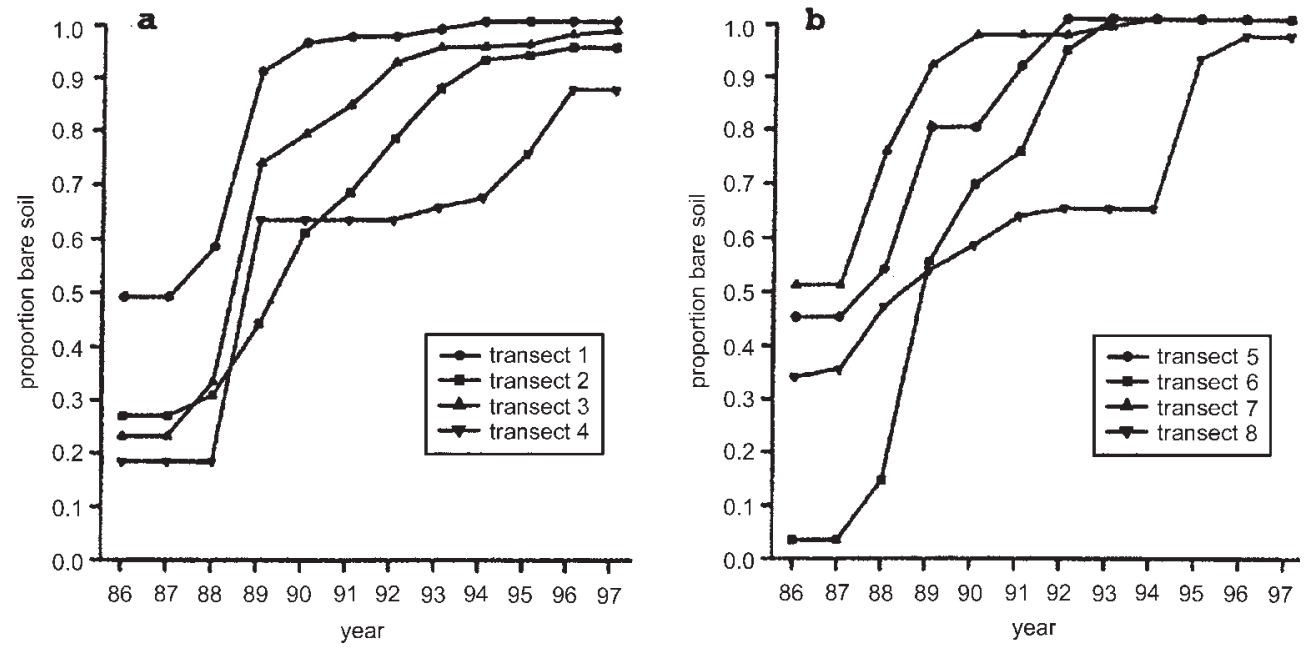

Fig. 2. Increases in the proportion of bare soil ( $<2 \%$ plant cover) for 4 transects on each of 3 intertidal marshes at La Pérouse Bay, Manitoba from 1986 to 1997 inclusive; a. Western intertidal salt marsh; b. Salt marshes on islands in Wawa Creek estuary; c. Eastern intertidal salt marsh.

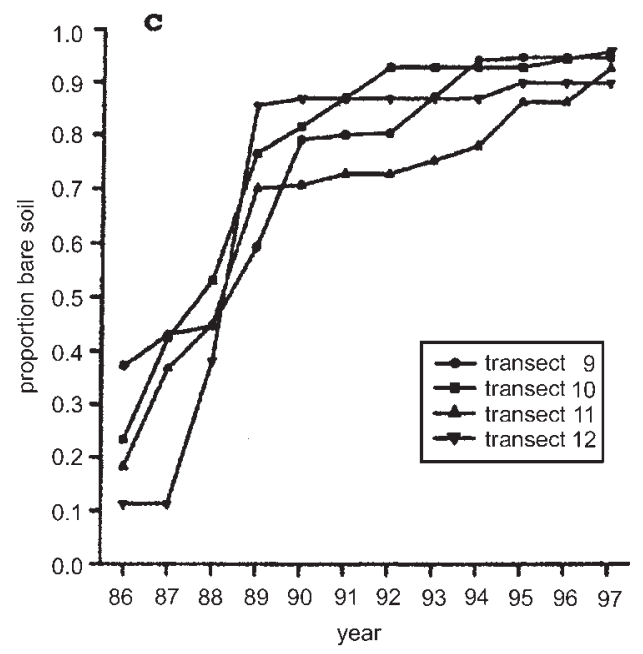


Table 2. Analyses of data by marsh and transect of loss of vegetated state and the change to bare sediment based on intertidal marsh, transect and year at La Pérouse Bay, Manitoba between 1986 and 1997. Both 3rd and 2nd order interactions are included for each intertidal marsh. $P<0.0001$ for all cases.

\begin{tabular}{clcr}
\hline Marsh and transect & Source & df & Wald statistic $^{\mathrm{b}}$ \\
\hline Western intertidal marsh & State*year & 11 & 41549.85 \\
& State*year*transect & $29^{\mathrm{a}}$ & 4765.711 \\
Transect 1 & State*year & $7^{\mathrm{a}}$ & 26816.94 \\
Transect 2 & State*year & 11 & 13060.30 \\
Transect 3 & State*year & 11 & 33646.87 \\
Transect 4 & State*year & 11 & 4966.00 \\
Wawa Creek estuary & State*year & 11 & 17341.27 \\
& State*year*transect & $18^{\mathrm{a}}$ & 5709.86 \\
Transect 5 & State*year & $5^{\mathrm{a}}$ & 1949.34 \\
Transect 6 & State*year & $6^{\mathrm{a}}$ & 7229.98 \\
Transect 7 & State*year & $7^{\mathrm{a}}$ & 5662.30 \\
Transect 8 & State*year & 11 & 12543.00 \\
& & & \\
Eastern intertidal marsh & State*year & 11 & 54158.21 \\
& State*year*transect & 33 & 5537.42 \\
Transect 9 & State*year & 11 & 17823.38 \\
Transect 10 & State*year & 11 & 12784.92 \\
Transect 11 & State*year & 11 & 12450.00 \\
Transect 12 & State*year & 11 & 14944.00
\end{tabular}

a Degrees of freedom depart from expectation owing to cells containing sampling $0 \mathrm{~s}$ (see text). ${ }^{\mathrm{b}}$ Concordant results were found using log-ratio chisquare values of reduced order models (Stokes et al. 2000).

was a general pattern of increase in the proportion of bare soil. To gain further insight as to the type of pattern, we examined the changes in the relative distribution of the habitat types for each transect with respect to 3 specific processes: additive, geometric and exponential. The results of fitting the observed data to the expectations from the models are summarized in Table 3. In all cases, the observed data departed significantly from the model projections. We conclude that the pattern of change in the distribution of habitat types is not linear (failure to fit the additive model), nor does it conform to either of the simple, single-phase, non-linear processes that we examined. We resist the temptation to build post-hoc models that would mimic the 12 sets of observational data.

\section{Long-term changes in above-ground biomass in grazed swards}

The above-ground biomass in the western intertidal salt marsh for most growing seasons between 1979 and 1999 is shown in Fig. 3. From 1979 to 1986 the maximum standing crop was between 40 and $60 \mathrm{~g} \mathrm{~m}^{-2}$ in July; when measured, lower values were recorded in May, June and August in any particular year. The estimated size of the breeding population was between 5000 and 16000 pairs of birds during these years (Cooke et al.
Table 3. Log ratio chi-square values for the transect data relative to the 3 processes. Critical value for significance of the Bonferroni adjusted value of $P \leq 0.05 / 36 \leq 0.001=29.59$.

\begin{tabular}{rrrr}
\hline Transect & $\begin{array}{c}\text { Additive } \\
\text { process }\end{array}$ & $\begin{array}{c}\text { Geometric } \\
\text { process }\end{array}$ & $\begin{array}{c}\text { Exponential } \\
\text { process }\end{array}$ \\
\hline 1 & 51540.60 & 65487.82 & 20021.06 \\
2 & 3418.79 & 7906.56 & 1526.64 \\
3 & 24136.05 & 46665.30 & 3421.26 \\
4 & 1451.32 & 3642.81 & 1052.21 \\
5 & 5382.67 & 7286.32 & 2760.06 \\
6 & 14629.45 & 51262.88 & 8113.16 \\
7 & 11581.82 & 14524.26 & 1430.81 \\
8 & 2338.15 & 3194.20 & 14084.42 \\
9 & 7020.62 & 12481.60 & 1391.84 \\
10 & 13172.25 & 24272.47 & 2815.54 \\
11 & 7512.36 & 19739.53 & 2542.72 \\
12 & 18661.43 & 39123.56 & 11422.85 \\
\hline
\end{tabular}

$1995)$ in later years numbers of geese increased considerably. As a result the proportion of bare sediment increased in 1988-1989 along the permanent vegetation transects (Fig. 2), thereby severely limiting the area of available forage, but the standing crop of remaining swards declined under intense grazing between 1988 and 1989 towards the present maximum values of only 20 to $30 \mathrm{~g}$ $\mathrm{m}^{-2}$ in July. When the standing crop is at this level, or lower, damage to pseudostems of Puccinellia is frequent.

\section{Long-term changes in faecal densities in grazed swards}

Concomitant with the increase in the proportion of bare sediment and the decline in standing crop in the western intertidal salt marsh in the late 1980s and early 1990s were peak rates of faecal deposits on the marsh in July (Fig. 4), values reached between 15 and 22 faecal pellets $\mathrm{m}^{-2} \mathrm{wk}^{-1}$. In earlier and later years maximum values ranged between 7 and 13 pellets $\mathrm{m}^{-2} \mathrm{wk}^{-1}$. In 1998 and 1999 minimum values for some weeks were above zero, a reflection of the presence of Ross and Canada geese on the marsh in increasing numbers. In the 2 seasons prior to 1998 faecal droppings of lesser snow geese were absent on some sampling occasions. However, in spite of the presence of these species overall numbers of geese have not reached densities comparable to those recorded in earlier years based on both faecal counts and direct observations (B. Pezzanite unpubl. data).

Overall, the data indicate that a threshold in the state of the marsh was reached in the late 1980s and early 1990s, this was associated with high densities of geese which, in turn, led to a decrease in the vegetated area and a decline in maximum standing crop of the remaining grazed swards of Puccinellia and Carex. Despite the reduction in faecal densities in subsequent years the vegetation has not recovered. 


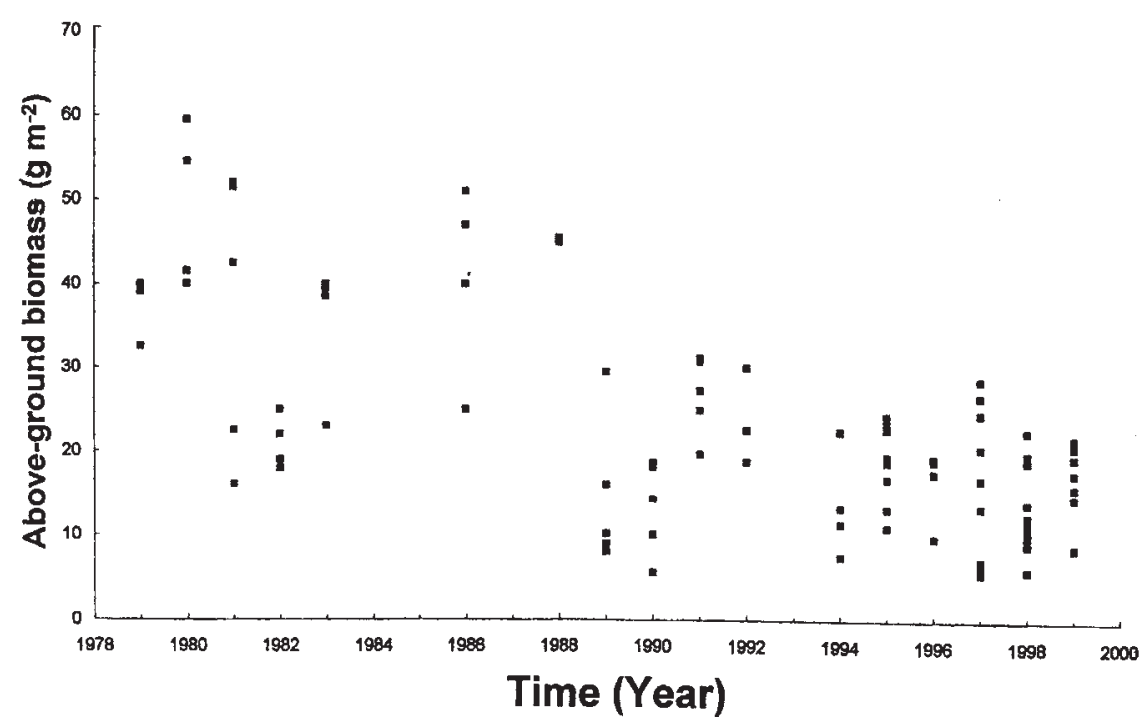

Fig. 3. Above-ground biomass $\left(\mathrm{g} \mathrm{m}^{-2}\right)$ from 1979 to 1999 on the western intertidal marsh at La Pérouse Bay, Manitoba $(n=6)$.

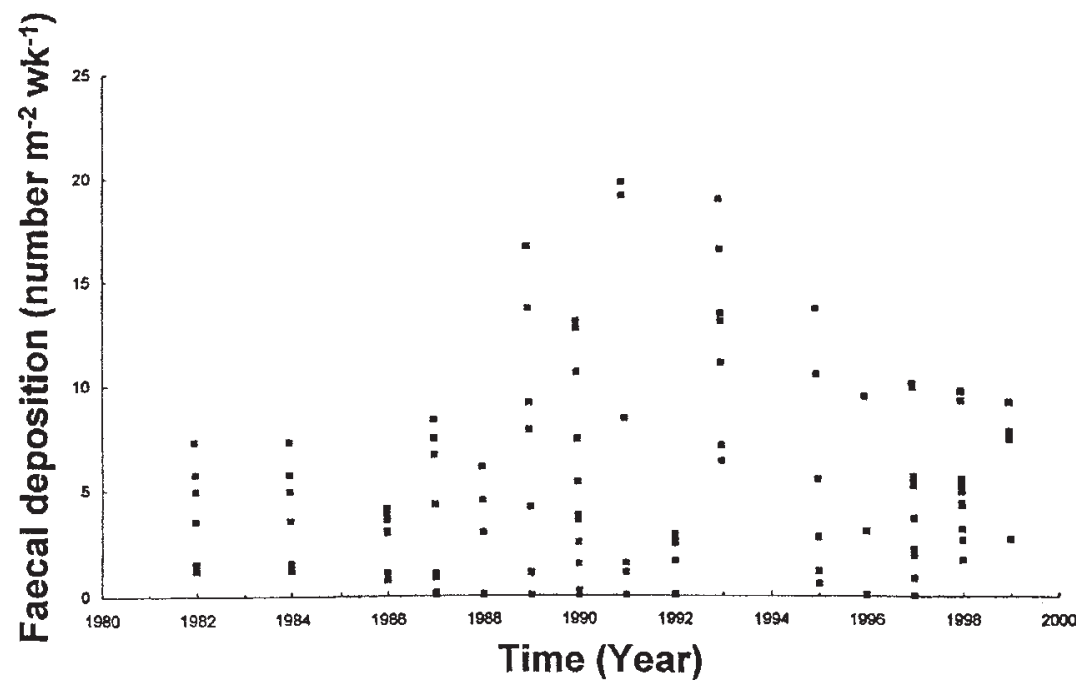

Fig. 4. Faecal deposition rate (no. $\left.\mathrm{m}^{-2} \mathrm{wk}^{-1}\right)$ on the western intertidal marsh at La Pérouse Bay, Manitoba $(n=6)$ from $1982-1999$.

Fig. 5. Summary of sequence of vegetation and soil changes on intertidal flats at $\mathrm{La}$ Pérouse Bay, Manitoba in response to intense foraging by increasing numbers of lesser snow geese (modified after Handa et al. 2002 and Chang et al. 2001).
Sequence of Change on Intertidal Flats

in Response to Intense Foraging by Geese

\begin{tabular}{c|c|c|c}
$\begin{array}{c}\text { Continuous sward } \\
\text { develops of Puccinellia } \\
\text { phryganodes and a low } \\
\text { presence of Carex } \\
\text { subspathacea, moss and } \\
\text { associated }\end{array}$ & $\rightarrow$ & $\begin{array}{l}\text { antense grubbing } \\
\text { and heavy } \\
\text { grazing pressure } \\
\text { from high } \\
\text { numbers of } \\
\text { dicotyledonous species }\end{array}$ & $\begin{array}{l}\text { a) Loss of vegetation } \\
\text { hypersaline conditions } \\
\text { geese, in part, } \\
\text { related to }\end{array}$ \\
climatic events & c) Erosion of surface \\
& organic layer and \\
& consolidated sediments \\
& d) Loss of seed bank \\
& e) Low frequency of \\
& annual halophytes \\
& establish
\end{tabular}




\section{Discussion}

It is well known that herbivores can modify the vegetational mosaic of landscapes at different spatial scales (Wiens 1976, 1985; Huntly 1991). Depending on the scale, landscapes may become more or less homogeneous over time with respect to plant cover in response to intense herbivory. The population increases of geese have increased forage demands over large spatial scales resulting in deleterious changes to the vegetation especially between 1984 and 1993 that was detected by LANDSAT imagery (Jano et al. 1998). The data presented in this paper indicate that most losses occurred in 1988 and 1989. Although losses along individual transects were not synchronous, all transects had a dramatic decrease in vegetative cover in the late 1980s. Temporal differences in the loss of vegetation between marshes suggest that the loss was not the outcome of a single foraging event, but the cumulative direct and indirect effects of the foraging activities of the birds.

Grubbing of roots and rhizomes provides valuable food resources for geese prior to above-ground growth of vegetation (Ganter \& Cooke 1996). In the absence of vegetation, hypersaline conditions develop in bare sediments due to increased evaporation and accumulation of marine salts in surface layers (Srivastava \& Jefferies 1995b, 1996). Salinities in surface layers frequently exceed $66 \mathrm{~g} \mathrm{l}^{-1}$ of solute (double that of seawater) and such concentrations are deleterious to graminoid growth (Srivastava \& Jefferies 1995a, 1996). The loss of vascular plants in spring when surface layers of soil are water-saturated is frequently accompanied by the development of an algal mat of cyanobacteria and diatoms. In late spring the mat is soft and potentially penetrable by new shoots, but clonal regrowth of Puccinellia and Carex is minimal at low temperatures $\left(<5^{\circ} \mathrm{C}\right)$. By the time temperatures have risen, the mat has dried out and become a hard crust. Graminoids cannot establish clonally either in the crust or in dry, exposed, hypersaline sediment where the crust has been removed by wind action. Hence, the absence of plant cover is the outcome of interacting biotic and abiotic events that extend across seasons. Puccinellia phryganodes is a sterile triploid (Bowden 1961) and where Carex subspathacea is grazed it rarely flowers. Thus, both species are dependent on stoloniferous and rhizomatous growth for re-establishment following grazing and grubbing. The interactions cannot be described by simple linear, geometric or exponential functions but represent multiphasic processes that are the consequence of above events. These results contrast with those of Bertness (1991) and Bertness \& Shumway (1993) on the re-colonisation of large bare saline patches in the high marsh zone in New England salt marshes created by wrack deposition. Here the initial colonisers reduce soil salinity and facilitate the invasion of less salt-tolerant plants that are competitively dominant, so that plant cover is re-established. Only when a patch of sediment has a diameter of $20 \mathrm{~cm}$ or less does inward clonal growth of graminoids from adjacent swards lead to reestablishment of plant cover within $2 \mathrm{yr}$ (McClaren unpubl.).

Changes in vegetation documented in this paper have been exacerbated indirectly by climate change (Findlay \& Deptuch-Stapf 1991; Skinner et al. 1998). The region has experienced a net negative temperature anomaly in recent decades compared to the mean temperature since 1950. In 1974, 1983, 1986, 1990 and 1992 the temperature anomaly was particularly marked and snow melt occurred later in the season at northern sites (Boyd unpubl. results). Northward migration of staging birds was delayed and the birds remained on the Cape Churchill peninsula and elsewhere until conditions improved further north, exacerbating the deleterious effects of grubbing.

Catastrophic events are characteristic of most ecosystems (Holling 1973) and are episodic and unpredictable, often resulting from the synergistic interaction of 2 or more unrelated discrete ecological processes (Odum 1971; Ehrlich \& Roughgarden 1987; Myers 1992). The processes, which may be abiotic or biotic, are synergistic and are a consequence of feedbacks operating at different spatial and temporal scales reinforcing the effect of the synergistic interaction (DeAngelis et al. 1986). The geese trigger an apparent trophic cascade that not only results in loss of vegetation and changes in soil properties but adversely affects soil microbial activity, invertebrate populations and local populations of passerines (Rockwell et al. ms). Results from short-term experimental studies conducted at La Pérouse Bay during the last $20 \mathrm{yr}$ are a robust predictor of these long-term changes (cf. Jefferies 1998, 1999; Bazely \& Jefferies 1997).

The above conceptual framework best describes the threshold patterns of change in plant cover and in soil and ecosystem properties associated with the effects of foraging by increasing numbers of geese (Fig. 5). A positive feedback between the foraging effects of geese, changes in soil properties (including the onset of hypersalinity) and loss of grazing swards describes the desertification of the intertidal salt-marsh soils (Srivastava \& Jefferies 1996). Very small changes in loss of plant cover at, or about, a threshold can be expected to result in disproportionately large changes in soil properties, including erosion of soil and increases in soil temperature (Iacobelli \& Jefferies 1991; Ruess et al. 1997). These changes lead to poor plant re-establishment and growth (Graetz 1991; Rietkerk et al. 1996; 
Handa \& Jefferies 2000; Handa et al. in press) and impoverishment of the affected terrestrial ecosystem (Dregne 1983). In the case of the La Pérouse Bay salt marshes, loss of vegetation reached such a threshold by the combined effects of an increasing goose population and a series of late snow melts in the north Hudson Bay region delaying spring migration. Although herbivores can trigger changes between stable states, it is ultimately the interactions between lack of vegetation cover and soil properties that move the system to a new stable state.

Acknowledgements. We thank members of the La Pérouse Field Station, the Hudson Bay Project, Parks Canada and the Churchill Northern Studies Centre for field and logistic support. We gratefully acknowledge financial support from the Natural Science and Engineering Research Council of Canada, the Department of Indian and Northern Affairs and Northern Development, the Arctic Goose Joint Venture, and the Central and Mississippi Flyway Councils. Professor J.P. Bakker, Professor R.H. Marrs and an anonymous referee provided helpful comments and advice that improved the quality of the manuscript. Mrs. Catherine Siu kindly typed the final version of this manuscript.

\section{References}

Abraham, K.F., Jefferies, R.L., Rockwell, R.F. \& MacInnes, C.D. 1996. Why are there so many white geese in North America? In Ratti, J.T. (ed.) Seventh International Waterfowl Symposium, pp. 79-82. Ducks Unlimited, Memphis, TN.

Alisaukas, R.T. \& Ankney, C.D. 1992. Winter diets and nutrition of mid-continental lesser snow geese. J. Wildlife Manage. 56: 53-54.

Bazely, D.R. \& Jefferies, R.L. 1997. Trophic interactions in arctic ecosystems and the occurrence of a terrestrial trophic cascade. In: Woodin, S.J. \& Marquiss, M. (eds.) Ecology of arctic environments. pp. 183-208. Blackwell Science, Oxford, UK.

Bertness, M.D. 1991. Interspecific interactions among high marsh perennials in a New England salt marsh. Ecology 72: 125-137.

Bertness, M.D. \& Shumway, S.W. 1993. Competition and facilitation in marsh plants. Am. Nat. 142: 718-724.

Bishop, Y.M.M., Feinberg, S.E. \& Holland, P.W. 1975. Discrete multivariate analysis: theory and practice. MIT Press, Cambridge, MA.

Bowden, K.M. 1961. Chromosome numbers and taxonomic notes on northern grasses IV. Tribe Festuca: Poa and Puccinellia. Can. J. Bot. 39: 123-128.

Cargill, S.M. \& Jefferies, R.L. 1984. The effects of grazing by lesser snow geese on the vegetation of a sub-arctic saltmarsh. J. Appl. Ecol. 21: 669-686.

Chang, E.R., Jefferies, R.L. \& Carleton, T. J. 2001. Relationship between vegetation and soil seed banks in an arctic coastal marsh. J. Ecol. 89: 367-384

Cooke, F., Rockwell, R.F. \& Lank, D.B. 1995. The snow geese of La Pérouse Bay, natural selection in the wild. Oxford University Press, Oxford, UK.

Crawley, M.J. 1983. Herbivory. Blackwell, Oxford, UK.

DeAngelis, D.L. 1992. Dynamics of nutrient cycling and food webs. Chapman \& Hall, London, U.K.

DeAngelis, D.L., Post, W.M. \& Travis, C.C. 1986. Positive feedback in natural systems. Springer-Verlag, Berlin, DE.

Dregne, H.E. 1983. Desertification of arid lands. Harwood, New York, NY.

Ehrlich, P.R. \& Roughgarden, J. 1987. The science of ecology. MacMillan Press, New York, NY.

Everitt, B.S. 1992. The analysis of contingency tables. Chapman \& Hall, London, UK.

Fienberg, S.E. 1980. The analysis of cross-classified categorical data. MIT Press, Cambridge, MA.

Findlay, B.F. \& Deptuch-Stapf, A. 1991. Colder than normal temperatures over north eastern Canada during the 1980's. Climatic Perspectives 13 (April): 9-12.

Gadallah, F.L. \& Jefferies, R.L. 1995. Forage quality in brood rearing areas of the lesser snow goose and the growth of captive goslings. J. Appl. Ecol. 32: 276-287.

Ganter, B. \& Cooke, F. 1996. Pre-incubation feeding activities and energy budgets by Snow Geese: can food on the breeding ground influence fecundity? Oecologia 106: 153165.

Graetz, R.D. 1991. Desertification: a tale of two feedbacks. In :Mooney, H.A., Medina, E., Schindler, D.W., Schulze, E.D. \& Walker, B.H. (eds.) Ecosystem experiments. Scope 45, pp. 59-87. John Wiley, New York, NY.

Handa, I.T. \& Jefferies, R.L. 2000. Assisted revegetation trials in degraded salt marshes of the Hudson Bay lowlands. $J$. Appl. Ecol. 37: 944-958.

Handa, I.T., Harmsen, R. \& Jefferies, R.L. In press. Patterns of vegetation change and the recovery potential of degraded areas in a coastal marsh system of the Hudson Bay lowlands. J. Ecol. 90.

Hansell, R.I.C., Scott, P.A., Staniforth, R.J. \& Svoboda, J. 1983. Permafrost development in the intertidal zone at Churchill, Manitoba. A possible mechanism for accelerated beach uplift. Arctic 36: 195-203.

Harper, J.L. 1969. The role of predation in vegetational diversity. Brookhaven Symp. Biol. 22: 48-62.

Hik, D.S., Jefferies, R.L. \& Sinclair, A.R.E. 1992. Foraging by geese, isostatic uplift and asymmetry in the development of salt-marsh plant communities. J. Ecol. 80: 395-406.

Hobaugh, W.C., Stutzenbaker, C.D. \& Flickinger, E.L. 1989. The rice prairies. In: Smith, L.M., Pederson, R.L. \& Kaminski, R.M. (eds.) Habitat management of migrating and wintering waterfowl in North America, pp. 367-383. Texas Technical University Press, Lubbock, TX.

Holling, C.S. 1973. Resilience and stability of ecological systems. Annu. Rev. Ecol. Syst. 4: 1-23.

Huntly, N.J. 1991. Herbivores and the dynamics of communities and ecosystems. Annu. Rev. Ecol. Syst. 22: 477-504.

Iacobelli, A. \& Jefferies, R.L. 1991. Inverse salinity gradients in coastal marshes and the death of Salix; the effects of grubbing by geese. J. Ecol. 79: 61-73.

Jano, A.P., Jefferies, R.L. \& Rockwell, R.F. 1998. The detection of change by multitemporal analysis of LANDSAT 
data: the effects of goose foraging. J. Ecol. 86: 93-99.

Jefferies, R.L. 1988. Pattern and process in arctic coastal vegetation in response to foraging by lesser snow geese. In: Gottlieb, L.D. \& Jain, S.K. (eds.) Plant evolutionary biology. pp. 341-369. Chapman \& Hall, London, UK.

Jefferies, R.L. 1999. Herbivores, nutrients and trophic cascades in terrestrial environments. In: Olff, H., Brown, V.K. \& Drent, R.H. (eds.) Herbivores: between plants and predators. Blackwell Science, Oxford, UK.

Jefferies, R.L., Jensen, A. \& Abraham, K.F. 1979. Vegetational development and the effect of geese on vegetation at $\mathrm{La}$ Pérouse Bay. Can. J. Bot. 57: 1439-1450.

Jefferies, R.L., Henry, H. \& Abraham, K.F. In press. Agricultural nutrient subsidies to migratory geese and ecological change to Arctic coastal habitats. In: Polis, G.A. \& Power, M.E. (eds.) Food webs at the landscape level. University of Chicago Press, Chicago, IL.

Lawton, J.H. 1989. Food webs. In: Cherrett, J.M. (ed.) Ecological concepts, pp. 43-78. Blackwell, Oxford, UK.

Maruyama, M. 1963. The second cybernetics: deviation amplifying mutual causal processes. Am. Sci. 51: 164-179.

May, R.M. 1977. Thresholds and breakpoints in ecosystems with a multiplicity of stable states. Nature 269: 471-477.

Myers, N. 1992. Synergisms: joint effects of climate change and other forms of habitat destruction. In: Peters. R.L. \& Lovejoy, T.E. (eds.) Global warming and biological diversity. pp. 344-354. Yale University Press, New Haven, NJ.

Noy-Meir, I. 1975. Stability of grazing systems: an application of predator-prey graphs. J. Ecol. 63: 459-481.

Odum, E.G. 1971. Fundamentals of Ecology, 3rd ed. Saunders, Philadelphia, PA.

Oksanen, T. 1990. Exploitation ecosystems in heterogenous habitat complexes. Evol. Ecol. 4: 220-234.

Olff, H., Brown, V.K. \& Drent, R.H. (eds.) 1999. Herbivores: between plants and predators. Blackwell Science, Oxford, UK.

Paine, R.T. 1969. A note on trophic complexity and community stability. Am. Nat. 103: 91- 93.

Polis, G.A. 1999. Why are parts of the world green? Multiple factors control productivity and the distribution of biomass. Oikos 86: 3-15.

Polis, G.A. \& Strong, D.R. 1996. Food web complexity and community dynamics. Am. Nat. 147: 813-846.

Porsild, A.E. \& Cody, W.J. 1980. Vascular plants of Continental Northwest Territories, Canada. National Museum of Canada, Ottawa, CA.
Power, M.E. 1992. Top down and bottom up forces in food webs: do plants have primacy? Ecology 73: 733-746.

Rietkerk, M., Ketner, P., Stroosnyder, L. \& Prins, H.H.T. 1996. Sahelian rangeland development: a catastrophe? J. Range Manage. 49: 512-519.

Ruess, R.W., Uliassi, D.D., Mulder, C.P.H. \& Person, B.T. 1997. Growth responses of Carex ramenskii to defoliation, salinity, and nitrogen availability: Implications for vegetation-geese-ecosystem dynamics in western Alaska. Écoscience 4: 170-179.

Sinclair, A.R.E. 1995. Equilibria in plant-herbivore interactions. In: Sinclair, A.R.E. \& Arcese, P. (eds.) Serengeti: dynamics, management, and conservation of an ecosystem. pp. 91-113. University of Chicago Press, Chicago, IL.

Skinner, W.R., Jefferies, R.L., Carleton, T.J., Rockwell, R.F. \& Abraham, K.F. 1998. Prediction of reproductive success and failure in lesser snow geese based on early season climatic variables. Global Change Biol. 4: 3-16.

Srivastava, D.S. \& Jefferies, R.L. 1995a. The effect of salinity on leaf and shoot demography of two arctic forage species. J. Ecol. 83: 421-436.

Srivastava, D.S. \& Jefferies, R.L. 1995b. Mosiacs of vegetation and soil salinity: a consequence of goose foraging in an arctic salt marsh. Can. J. Bot. 73: 75-83.

Srivastava, D.S. \& Jefferies, R.L. 1996. A positive feedback: herbivory, plant growth, salinity, and the desertification of an arctic salt marsh. J. Ecol. 84: 31-42.

Stokes, M.E., Davis, C.S. \& Koch, G.G. 2000. Categorical data analysis using the SAS $S^{R}$ system. 2nd ed. SAS Institute, Cary, NC.

Strong, D.R. 1992. Are trophic cascades all wet? Differentiation and donor control in species ecosystems. Ecology 73 : 747-754.

van de Koppel, J., Rietkerk, M. \& Weissing, F.J. 1997. Catastrophic vegetation shifts and soil degradation in terrestrial grazing systems. Trends Ecol. Evol. 12: 352-356.

Weins, J.A. 1976. Population responses to patchy environments. Annu. Rev. Ecol. Syst. 7: 81-120.

Weins, J.A. 1985. Vertebrate responses to environmental patchiness in arid and semi-arid ecosystems. In: Pickett, S.T.A. \& White, P.S. (eds) The ecology of natural disturbance and patch dynamics, pp. 169-193. Academic Press, San Diego, CA.

Westoby, M., Walker, B.H. \& Noy-Meir, I. 1989. Opportunistic management for rangelands not at equilibrium. $J$. Range Manage. 42: 265-273.

Received 11 June 2001; Revision received 15 October 2001; Accepted 15 October 2001. Coordinating Editor: J.P. Bakker. 